\title{
The appearance of taxonomical distance among winter cereal species along the spring to early summer SPAD values in different cropyears
}

\author{
Ákos TARNAWA ${ }^{1}$-Kristóf SZABÓ ${ }^{1}$ - Ferenc NYÁRAI-HORVÁTH ${ }^{1}$ - András MÁTÉ $^{1}$ - \\ Zsolt SZENTPÉTERY ${ }^{2}$ \\ 1: Institute of Crop Production, Szent István University, 2100 Gödöllő, Páter K. u. 1; \\ E-mail: tarnawa.akos@mkk.szie.hu \\ 2: Faculty of Mechanical Engineering, Szent István University, 2100 Gödöllő, Páter K. u. 1
}

Keywords: cereal, SPAD value

\section{Introduction}

Agricultural production has long been a major issue in Hungary, as almost half of the country's land is arable. In Hungary, just as in the entire world, cereals represent the most plausible source of human alimentation, hence, for a very long time, winter cereals were the most commonly cultivated crop species. There exist numerous factors that have effect on yield (Tarnawa \& Klupács, 2006; Horváth, 2014; Kende, 2017) and the cropyear is an essential one (Jolánkai, 2018). Most critical technological points in winter cereal production are agrochemical applications, so that it is important to reveal and study soundly their impacts (Birkás, 2006). The nitrogen regime of plants has high importance in photosynthetic activity. Strong connection could be found even visually between the colour of a crop plant and $\mathrm{N}$ supply. That colour, and in parallel the chlorophyll activity can be estimated in an objective way by SPAD analyzer that generates indices on $\mathrm{N}$ supply of plants on field. As it measures without destruction, it can be used in different phenological status (Ványiné, 2008). To be able to use the SPAD method for $\mathrm{N}$ supply estimation it is necessary to have points to accord. In former studies it was found that even between varieties there can be observed big differences in SPAD values. In this paper our aim is to make reference values for the most critical lifetime of several species and varieties of winter cereals.

\section{Materials and methods}

A set of winter cereals were sown on micro-plots $\left(1 \mathrm{~m}^{2}\right.$ each) for demonstrational purposes at the Gödöllő campus of Szent István University. Among these items different sort of winter cereals could be found. Four groups were formed on them: 1 - Triticum aestivum; 2 - other Triticum; 3 - nude cereals but not Triticum; 4 - other cereals in glumous. In one of the most critical period, the late spring to early summer, chlorophyll activity was estimated by SPAD-502 PLUS analyzer in different phenological stages. In two cropyears the estimations were made for several times (weekly). The SPAD values were measured on them regularly in 10 repetitions for each plot in each time. On the series the statistical analysis was performed by using the MS Excel program package.

\section{Results and discussion}

The analysis were made by group each cropyear, compared also with the averages of other groups as reference. On figure 1 the results of group 4 compared with the average of other three groups can be seen in both cropyears. 


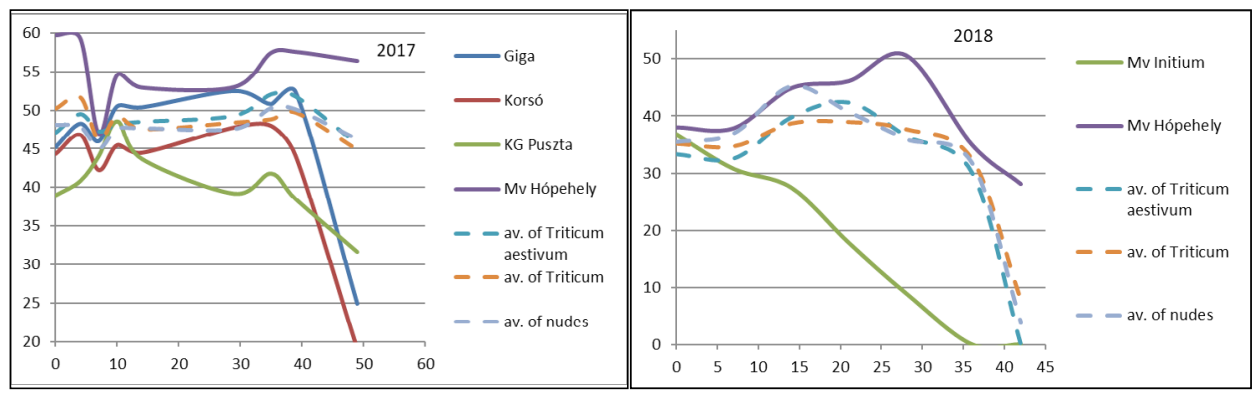

Figure 1: The average result for glumous cereals (group 4) with the combined average of Triticum aestivum varieties (group 1), Triticum varieties (group 2) and non-Triticum nude cereals (group 3) in 2017 and 2018

It can be stated that remarkable differences occurred between the averages that depend on the cropyear as well. Also, the differences show close correlation with taxonomical distances of the species and varieties examined.

\section{Conclusions}

Evaluating the results obtained it can be concluded that it is necessary to have reference values not only for each species but for every variety and every cropyear. The differences in pattern of averages seem to be correlated with taxonomical distances of the varieties examined but given years' results varying by the cropyear.

\section{Acknowledgement}

The authors are indebted regarding the financial support of VKSZ (VKSZ_12-1-20130034 - Agrárklíma.2) and NVKP (NVKP_16-1-2016-0016).

\section{References}

Birkás, M., Dexter, A. R., Kalmár, T., Bottlik, L. (2006): Soil quality - soil condition - production stability. Cereal Research Comm. 34. 1. 135-138. DOI: 10.1556/CRC.34.2006.1.34

Horváth, Cs. (2014): Storage proteins in wheat (Triticum aestivum L.) and the ecological impacts affecting their quality and quantity, with a focus on nitrogen supply. Columella - Journal of Agricultural and Environmental Sciences 1. 2. 57-75 pp.

Jolánkai, M., Kassai, M. K., Tarnawa, Á., Pósa, B., Birkás, M. (2018): Impact of precipitation and temperature on the grain and protein yield of wheat (Triticum aestivum L.) varieties. IDÖJÁRÁS / QUARTERLY JOURNAL OF THE HUNGARIAN METEOROLOGICAL SERVICE $122: 1$ pp. 31-40. , 10 p.

Kende, Z., Sallai, A., Kassai, K., Mikó, P., Percze, A .,Birkás, M. (2017): The Effects of Tillage-Induced Soil Disturbance on Weed Infestation of Winter Wheat. POLISH JOURNAL OF ENVIRONMENTAL STUDIES 26: 3 pp. 1131-1138., 8 p.

Tarnawa, Á., Klupács, H. (2006): Element and energy transport model for an agricultural site. Cereal Research Communications. 34. 1. 85-89 pp.

Ványiné Széles, A. (2008): SPAD érték és a kukorica (Zea Mays L.) termésmennyisége közötti összefüggés elemzése különböző tápanyag - és vízellátottsági szinten. PhD doktori értekezés, Debrecen, p. 111. 